\title{
Forecasting Public Services Maladministration in Local Government
}

\author{
Tatiek Sri Djatmiati ${ }^{1}$, Tahegga Primananda Alfath ${ }^{2}$, Tresna Maulana Fahrudin ${ }^{3}$ \\ $\left\{\right.$ taheggaalfath@gmail.com $\left.{ }^{1}, 2\right\}$ \\ Faculty of Law Universitas Airlangga, Surabaya, Indonesia ${ }^{1}$ \\ Faculty of Law Universitas Airlangga, Surabaya, Indonesia ${ }^{2}$ \\ Faculty of Computer Science Universitas Narotama, Surabaya, Indonesia ${ }^{3}$
}

\begin{abstract}
Good local government was characterized by public services did not carry out maladministration. Maladministration was an act that contradicted the law or principles that are the basis. Eradication of maladministration was a problem because people did not know the forms of maladministration that occurred. This study provided a solution for maladministration prevention through forecast the forms of maladministration in local government and eradication of maladministration by legal approaches. Forecasting maladministration on public services in local government would be able to produce an analysis of local government policies in the prevention of current and future maladministration, in addition to generating estimates of future forms of maladministration. This study would provide an impact that local government could make prevention efforts through responsive legal policies. In the future, the ombudsman as an institution that had the authority to oversee state apparatus, it would also be easier to prevent and eradicate maladministration if assisted by the use of information technology.
\end{abstract}

Keywords: Maladministration, Local Government, Forecasting.

\section{Introduction}

There are two kinds of legal theory in law, the first is preventive legal protection, and namely, the people are given the opportunity to give their opinion before the decision from the government so that the government is more careful in making decisions. The second is repressive legal protection, namely the handling of legal protection for the people by a judicial institution.[1] Legal protection for the people is very much needed because the government, in this case, the public service provider has the opportunity and opportunity to abuse the authority. Abuse of authority can be in the form of maladministration or even corruption.

Based on data from the annual report of the Ombudsman of the Republic of Indonesia, the Regional Government always ranks first as the state institution with the most reported maladministration actions by the public. Even though the regional government is the closest public service to the community. The magnitude of the maladministration action on regional government administrators is not in accordance with the mandate contained in paragraph IV of the Opening of the State Constitution of the Republic of Indonesia (UUD NRI 1945) which has a goal, one of which is the welfare of the people. One measure of welfare progress is the creation of good public services by state administrators. 
Based on these problems, this study tries to find a way to eradicate or minimally reduce maladministration actions from the local government through forecasting methods. Forecasting is a method commonly used by scientific information technology to predict what will happen in the future with a database that has been collected and processed and perform mathematical calculations carefully. With the use of information technology, it is hoped that this research will become a preventive effort for regional governments to eradicate or at a minimum reduce the actions of local government administrators. So that the community will get good public services. The application of general principles of good governance can also be applied well by local government organizers. This research is also useful for the Ombudsman of the Republic of Indonesia to maximize preventive efforts in combating maladministration.

\section{Concept and Characteristics of Maladministration in Local Govern- ment}

Maladministration in Indonesia became known because it was mentioned in Article 1 Number 3 of Act Number 37 of 2008 concerning Ombudsman of the Republic of Indonesia, "Maladministration is behavior or act against the law, exceeds authority, uses authority to other objectives of which are the objectives of the authority, including negligence or neglect of legal obligations in the implementation of public services carried out by State Administrators and governments that cause material and / or immaterial losses to the community and individuals". Maladministration under the law has elements in the form of: (1) acts against the law, (2) abuse of authority (3) towards the implementation of public services (4) carried out by state and government officials, and (5) causing losses.

Unlawful acts as contained in the element of maladministration are actions that are contrary to the laws and regulations or underlying legal principles. This action has an element of error if done because of intentions, or because of negligence, and there is no justification or forgiving reason. The intentional element that is intended is that the person acts consciously and understands the consequences of the actions taken whereas the element of negligence which is intended in an act against the law is the existence of an act or ignoring something that should be done (an obligation of prudence) which can cause harm.

In the concept of maladministration contained in Law Number 37 of 2008, the maker seems to have realized about the difference in concepts between acts against the law and abuse of authority. Abuse of authority in the administrative legal concept is always associated with the concept of detournement de pouvoir, officials use their authority for other purposes that deviate from the objectives given to that authority. In contrast to acts against the law, that this action can be carried out because of an element of negligence, in the case of abuse of authority, the act is carried out consciously, namely to divert the purpose given to that authority. The transfer of goals is carried out on the basis of personal will, both for his personal interests and for others. However, in clause Article 1 Number 3 of Law Number 37 also states the clause goes beyond authority, which should not include abuse of authority, but does not have authority.

Authority is limited by three things: namely, substance, region (locus), and time (tempus) [2] Beyond this limit, government action is an act without authority (onbevoegheid). This is certainly different from the concept of abuse of authority as discussed earlier. The scope of government action includes three things, namely: authority, procedure, and substance. If government action is not based on these three things, then it can be declared a juridical defect. 
The existence of authority and procedures in the act of government is a formal legal basis, where there is a principle that applies thereafter, namely the principle of praesumptio iustae causa, the claim does not prevent the implementation of the decisions of the state administrative officials being sued.

The object of this maladministration is related to the implementation of public services. Examine the meaning of words from maladministration that comes from Latin. Malum which means evil (bad), and administrare which means serving. This poor service is carried out by public officials. The implementation of public services should pay attention to the code of conduct as a public official, as the European Ombudsman establishes the code of Good Administrative Behavior which contains the following principles: (1) lawfulness principle, (2) absence of discrimination, (3) proportionality principle, (4) absence of abuse, (5) impartiality and independency, (6) legitimate expectations and consistency, (7) fairness, (8) cortesy, (9) reasonable time limit for taking decisions.[3]

The implementation of public services should also pay attention to the principles of good governance. G.H. Addink argues that good governance is an appropriate use in government power in a transparent and participatory manner. This is related to the fundamental tasks of the government, namely: (1) To guarantee the security of all persons and society itself, (2) To manage an effective framework for the public sector, the private sector, and civil society, (3) To promote economic, social, and other according to the wishes of the population.

In the study of administrative law, general principles of good governance must be applied in the realization of good governance. First, the principle of legal certainty, this principle speaks that every government action must prioritize an appropriate and fair basis of legislation. Second, the principle of accuracy, public service providers must have accuracy in every decision making, considering all relevant facts so as not to cause harm. Third, the principle of prohibiting discrimination, this principle prohibits public service providers from treating the same. Fourth, the principle of transparency, public service providers should open themselves to the public to obtain their rights in obtaining information that is true, honest, and non-discriminatory.[4] Fifth, the principle of legitimate expectation, namely the organizers of public services must be a public trust, carry out in accordance with what was promised before.[5] Sixth, the principle of prohibition of arbitrary acts, namely the organizers of public services must be rational in carrying out all their actions. And seventh, the principle of abuse of authority, that public service providers are not allowed to use their authority deviating from the goal.

Government administrators constitute a subjective element in maladministration, that what is meant by government organizers here are public service providers. These public service providers include state administrators and the government including those held by State-Owned Enterprises, Regionally-Owned Enterprises, and State-Owned Legal Entities as well as private bodies or individuals who are given the task of carrying out certain public services that are partially or entirely sourced from the revenue budget. State expenditure and / or regional income and expenditure budget. Philipus Hadjon stated that every person or entity that has the public legal authority and is not included in the list of names of general government bodies as mentioned in the constitution must also be included, the form of a juridical organization does not matter.[1]

The element of maladministration action must have a result of causing losses, losses incurred in the form of material / or immaterial to the community or individuals. The losses incurred as a result of government administrators, including the regional government, heeded the so-called Dutch administrative law concept with the algemene normen van goed over- 
heidsged or beginselen van behoorlijk overheidsgedrag. Then the consequences for state administrators for maladministration are personal responsibility.

The concept of maladministration is a measure to determine the form of maladministration. Ombudsman as a state institution that has the authority to oversee the actions of state administrators, including regional government. Classifying the forms of maladministration that occur in regional governments are as follows: not providing services, prolonged delays, discrimination, inappropriate services, procedure deviations, conflict of interest, abuse of authority, not competent, and request for money, goods and service.

\section{Forecasting Maladministration on Public Services in Local Govern- ment}

\subsection{Forecasting Maladministration in Local Government}

Maladministration is a social problem, to reduce the number of maladministration cases can be solved through sustainable research using mathematical and statistical approaches, even the development of intelligent computing systems. As in this study, it starts from making data modeling using past data from several years ago that aims to predict the number of maladministration cases based on 9 aspects in the following year to make a policy or the right solution to reduce the number of maladministration cases. Forecasting is a method that can be applied to make data modeling by predicting events that will occur using past data and projecting it into the future with several forms of mathematical models [6]. Forecasting methods are often applied by several researchers because of the speed of getting predictive results, this study implemented the forecasting methods, namely Trend Moment with MAPE (Mean Absolute Percentage Error) measurement. A good forecasting model is a model that has small MAPE and has high accuracy. This research is expected to provide a different view that the use of science in the fields of mathematics, statistics and information technology can help predict the occurrence of maladministration at a time and the authorities can take policy.

\subsection{System Design}

Data forecasting modeling is applied to maladministration cases using Trend Moment Method Methods. The data period that is used to predict the number of maladministration in 2019 and 2020 is using past data for five years from 2014-2018. Both of these methods are compared to find a forecasting model that has a small error rate. The variable of maladministration that is involved in this research consists of 9 aspects such as Not Providing Services, Prolonged Delay, Discrimination, Inappropriate Services, Procedure Deviations, Conflict of Interest, Abuse of Authority, Not Competent, and Request for Money, Goods and Services. The number of maladministration cases in each aspect will be processed in the calculation using the forecasting method formula to predict the number of maladministration cases in the following year.

Trend Moment method calculates the data obtained by using equation 1.

$$
\sum Y=a * n+b * \sum X
$$


After getting the results of equation 1, it can be continued to calculate using equation 2 .

$$
\sum X Y=a * \sum X+b * \sum X^{2}
$$

The elimination of equation 1 and equation 2 are getting the values of $a$ and $b$, then both of these values are projected into the predictive equation 3[7].

$$
Y=a+b x
$$

Where:

$$
\begin{aligned}
& Y=\text { Predictive variable values } \\
& a=\text { constant number } \\
& b=\text { trend line coefficient } \\
& X=\text { time index }(0,1,2, \ldots \mathrm{n})
\end{aligned}
$$

After obtaining the predictive equation of Trend Moment, it will compare the result of actual data and forecast data. If the forecast data is close to actual data in each year, then the forecasting model has small MAPE and it is good accuracy.

Where:

$$
M A P E=\left(\frac{100 \%}{n}\right) \sum_{t=1}^{n} \frac{[X t-F t}{X t}
$$

$X t=$ Actual data on period $t$

$F t=$ Forecasting value on period $t$

$n=$ Total data

Figure 1 is illustrated the system design of forecasting maladministration research begins from the collecting data and variable of maladministration in 2014-2018, modeling the actual data, projecting the forecast data, and MAPE measurement. 

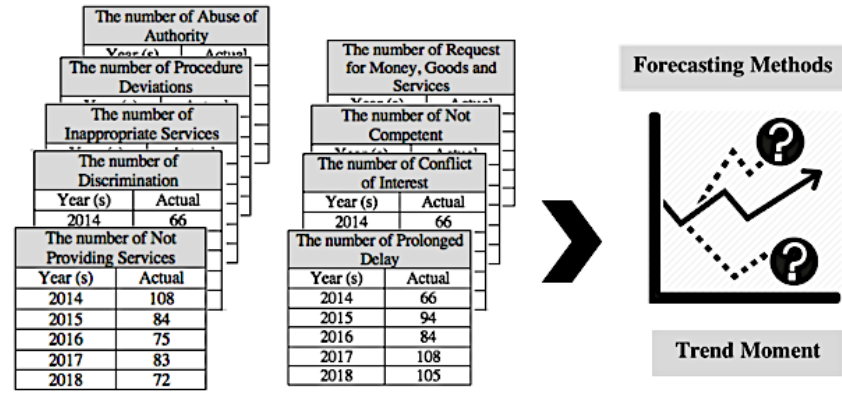

9 Aspects on Maladministration Data 2014- 2018
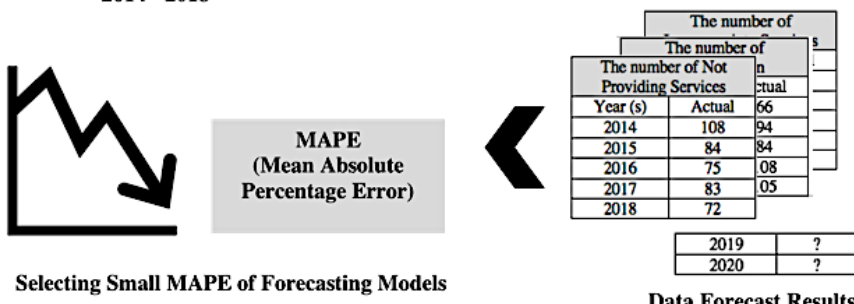

Selecting Small MAPE of Forecasting Model

Data Forecast Results

Fig.1. The system design of forecasting maladministration using Trend Moment Methods

\subsection{Population and Sample}

There are nine aspects of maladministration data in this research which the actual data based on the number of Not Providing Services, Prolonged Delay, Discrimination, Inappropriate Services, Procedure Deviations, Conflict of Interest, Abuse of Authority, Not Competent, and Request for Money, Good, and Services.

In Table 1, it can be seen that there was a decrease of $33.3 \%$ in the number of Not Providing Services from 2014 (108 cases) to 2018 (72 cases).

Table 1. The number of Not Providing Services cases

\begin{tabular}{cccc}
\hline Year $(\mathrm{s})$ & Actual Data & \% cases & Mean \\
\hline 2014 & 108 & $2014(108)$ & \\
2015 & 84 & to $2018(72)$ & $84.4 \sim$ \\
2016 & 75 & $=$ & 85 cases \\
2017 & 83 & $33.3 \%$ & \\
2018 & 72 & (decrease) & \\
\hline
\end{tabular}

In Table 2 show there was an increase of $37.1 \%$ in the number of Prolonged Delays from 2014 (66 cases) to 2018 (105 cases). 
Table 2. The number of Prolonged Delay cases

\begin{tabular}{cccc}
\hline Year (s) & Actual Data & \% cases & Mean \\
\hline 2014 & 66 & $2014(66)$ to & \\
2015 & 94 & $2018(105)=$ & \\
2016 & 84 & $37.1 \%$ & $91.4 \sim$ \\
2017 & 108 & (increase) & 91 cases \\
2018 & 105 & & \\
\hline
\end{tabular}

In Table 3 show there was a decrease of $71.4 \%$ in the number of Discrimination from 2014 ( 7 cases) to 2018 ( 2 cases).

Table 3. The number of Discrimination cases

\begin{tabular}{cccc}
\hline Year (s) & Actual Data & \% cases & Mean \\
\hline 2014 & 7 & $2014(7)$ to & \\
2015 & 4 & $2018(2)=$ & \\
2016 & 6 & $71.4 \%$ & $4.6 \sim$ \\
2017 & 4 & (decrease) & 5 cases \\
2018 & 2 & & \\
\hline
\end{tabular}

In Table 4 show there was an increase of $33.3 \%$ in the number of Inappropriate Services from 2014 ( 2 cases) to 2018 ( 3 cases).

Table 4. The number of Inappropriate Services cases

\begin{tabular}{cccc}
\hline Year $(\mathrm{s})$ & Actual Data & \% cases & Mean \\
\hline 2014 & 2 & $2014(2)$ to & \\
2015 & 3 & $2018(3)=$ & \\
2016 & 3 & $33.3 \%$ & $3.4 \sim$ \\
2017 & 6 & (increase) & 3 cases \\
2018 & 3 & & \\
\hline
\end{tabular}

In Table 5 show there was a decrease of $9.4 \%$ in the number of Procedure Deviations from 2014 (32 cases) to 2018 ( 29 cases).

Table 5. The number of Procedure Deviation cases

\begin{tabular}{cccc}
\hline Year (s) & Actual Data & \% cases & Mean \\
\hline 2014 & 32 & $2014(32)$ to & \\
2015 & 60 & $2018(29)=$ & \\
2016 & 25 & $9.4 \%$ & $36.4 \sim$ \\
2017 & 36 & $($ decrease $)$ & 36 cases \\
2018 & 29 & & \\
\hline
\end{tabular}


In Table 6 show there was an increase of $75 \%$ in the number of Conflict of Interest from 2014 (1 case) to 2018 (4 cases).

Table 6. The number of Conflict of Interest cases

\begin{tabular}{cccc}
\hline Year (s) & Actual Data & \% cases & Mean \\
\hline 2014 & 1 & $2014(1)$ to & \\
2015 & 2 & $2018(4)=$ & $3.6 \sim$ \\
2016 & 4 & $75 \%$ & 4 cases \\
2017 & 7 & (increase) & \\
2018 & 4 & & \\
\hline
\end{tabular}

In Table 7 show there was a decrease of $66.7 \%$ in the number of Abuse of Authority from 2014 (54 cases) to 2018 (18 cases).

Table 7. The number of Abuse of Authority cases

\begin{tabular}{cccc}
\hline Year $(\mathrm{s})$ & Actual Data & \% cases & Mean \\
\hline 2014 & 54 & $2014(54)$ to & \\
2015 & 51 & $2018(18)=$ & $47.8 \sim$ \\
2016 & 62 & $66.7 \%$ & 48 cases \\
2017 & 54 & (decrease) & \\
2018 & 18 & & \\
\hline
\end{tabular}

In Table 8 show there was a decrease of $67.2 \%$ in the number of Not Competent Services from 2014 (55 cases) to 2018 (18 cases).

Table 8. The number of Not Competent Service cases

\begin{tabular}{cccc}
\hline Year $(\mathrm{s})$ & Actual Data & $\%$ cases & Mean \\
\hline 2014 & 55 & $2014(55)$ to & \\
2015 & 35 & $2018(18)=$ & 48 cases \\
2016 & 65 & $67.2 \%$ & \\
2017 & 67 & (decrease) & \\
2018 & 18 & & \\
\hline
\end{tabular}

In Table 9 show there was an increase of $8.3 \%$ in the number of Request for Money, Goods, and Services from 2014 (11 cases) to 2018 (12 cases).

Table 9. The number of Request for Money, Goods and Service cases

\begin{tabular}{cccc}
\hline Year $(\mathrm{s})$ & Actual Data & \% cases & Mean \\
\hline 2014 & 11 & $2014(11)$ to & \\
2015 & 18 & $2018(12)=$ & 13 cases \\
2016 & 20 & $8.3 \%$ & \\
2017 & 4 & (increase) & \\
2018 & 12 & & \\
\hline
\end{tabular}




\subsection{Forecasting Maladministration Results}

Table 10 show there are 5 aspects which they have MAPE $<=30 \%$, it explained that the forecast data is close to actual data, and it represented the good forecasting model. Even MAPE below 10\% is owned by the aspect of a.) Not Providing Services (MAPE 8\%) and b.) Prolonged Delays (MAPE 9\%).

Table 10. Forecasting Maladministration Result with MAPE

\begin{tabular}{lccccc}
\hline No. & $\begin{array}{c}\text { Maladministration } \\
\text { Characteristic }\end{array}$ & $\begin{array}{c}\text { Forecasting 2019 } \\
\text { (cases) }\end{array}$ & $\begin{array}{c}\text { Forecasting } \\
2020 \\
\text { (cases) }\end{array}$ & $\begin{array}{c}\text { MAPE - Mean } \\
\text { Absolute Percentage } \\
\text { Error (\%) }\end{array}$ & $\begin{array}{c}\text { MAPE } \\
\text { Threshold }\end{array}$ \\
\hline 1 & Not Providing Services & $62.5 \sim 63$ & $55.2 \sim 55$ & 8 & MAPE $<=30 \%$ \\
2 & Prolonged Delays & 119 & $128.2 \sim 128$ & 9 & MAPE $<=30 \%$ \\
3 & Discrimination & $1.6 \sim 2$ & $0.6 \sim 1$ & 22 & MAPE $<=30 \%$ \\
4 & Inappropriate Services & $4.9 \sim 5$ & $5.4 \sim 5$ & 24 & MAPE $<=30 \%$ \\
5 & Procedure Deviations & $27.4 \sim 27$ & $24.4 \sim 24$ & 25 & MAPE $<=30 \%$ \\
6 & Conflict of Interest & $6.9 \sim 7$ & 8 & 31 & MAPE $>30 \%$ \\
7 & Abuse of Authority & $27.1 \sim 7$ & $20.2 \sim 20$ & 31 & MAPE $>30 \%$ \\
8 & Not Competent & $35.4 \sim 35$ & $31.2 \sim 31$ & 46 & MAPE $>30 \%$ \\
9 & Request for Money, & $9.4 \sim 9$ & $8.2 \sim 8$ & 61 & MAPE $>30 \%$ \\
\hline
\end{tabular}

Fig.2 has illustrated the good forecasting model (MAPE 8\%), we can use as the confidence of the model to predict the event of maladministration based on Not Providing Service aspects. The Trend Moment predicted that in the following year the events would be decreased in 2019 and 2020 with the total cases 63 and 55 respectively.

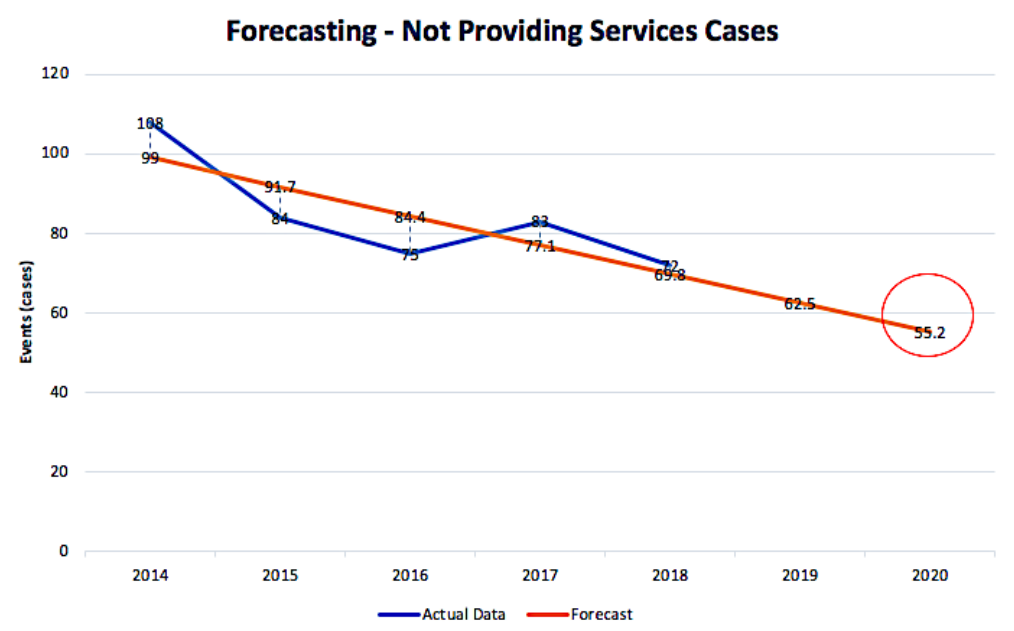

Fig.2. The good forecasting models based on Not Providing Service aspects with MAPE 8\%

While Fig.3 has illustrated also the good forecasting model (MAPE 9\%), we can use as the confidence of the model to predict the event of maladministration based on Prolonged 
Delays aspects. The Trend Moment predicted that in the following year the events would be increased in 2019 and 2020 with the total cases 119 and 128 respectively.

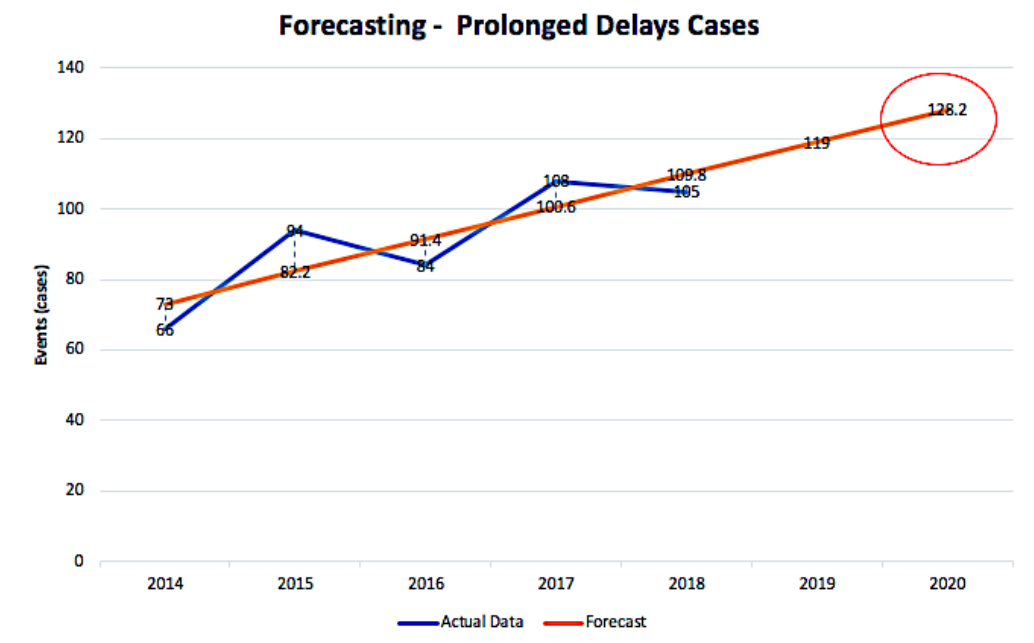

Fig.3. The good forecasting models based on Prolonged Delays aspects with MAPE 9\%

\section{Conclusion}

This study provides a preventive way to eradicate the maladministration actions that exist in local government, so that the government can better anticipate before the maladministration action occurs. Other than that the Ombudsman as a supervisory institution that oversees the actions of public service providers, can be easier in conducting a search for maladministration. The way to do this is by forecasting maladministration actions from the local government, and classifying them into a concept of maladministration through information technology data processing methods. With the results shown through forecasting, preventive measures to prevent maladministration in local government can be maximized. The development of future research will maximize information technology in law enforcement efforts, to make it easier for people to get justice.

Acknowledgments Thank you for the opportunity and funding from Universitas Narotama Surabaya, and as well as scientific contributions from Universitas Airlangga so that this research can work. did not forget the Ombudsman of the Republic of Indonesia Representative of East Java who had provided data related to reports of alleged maladministration in the East Java government.

\section{References}

[1] P. M. Hadjon, Perlindungan Hukum Bagi Rakyat Indonesia. Peradaban, 2007.

[2] P. M. Hadjon, Hukum Administrasi dan Good Governance. Jakarta: Penerbit Universitas Tri Sakti, 2010. 
[3] J. Mendes, "Good Administration in EU Law and the European Code of Good Administrative Behaviour," Ssrn, 2010.

[4] P. Dr. Tatiek Sri Djatmiati, "Transparency and Accountability in the Finance Management of the Local Government in Promoting Good Governance," IOSR J. Humanit. Soc. Sci., vol. 19, pp. 15-19, 2014.

[5] A. W. G. J. Buijze, The principle of transparency in EU Law. 2013.

[6] J. B. Heizer and Render, Manajemen Operasi, Buku 1 Edisi 9. Jakarta: Salemba Empat, 2009.

[7] Sugiarto and S. Dergibson, Metode Statistika Untuk Bisnis dan Ekonomi. Jakarta: PT Gramedia Pustaka Utama, 2002. 